OPEN ACCESS

Edited by:

Nadia Guerra,

Imperial College London, United Kingdom

Reviewed by:

Mary A. Markiewicz,

University of Kansas

Medical Center, United States

Daniel M. Altmann

Imperial College London,

United Kingdom

*Correspondence:

Marina Babic

marina.babic_cac@drfz.de

Specialty section:

This article was submitted

to T Cell Biology,

a section of the journal

Frontiers in Immunology

Received: 28 February 2018

Accepted: 15 May 2018

Published: 30 May 2018

Citation:

Babic M and Romagnani C (2018)

The Role of Natural Killer

Group 2, Member D in Chronic Inflammation and Autoimmunity.

Front. Immunol. 9:1219.

doi: 10.3389/fimmu.2018.01219

\section{The Role of Natural Killer Group 2, Member D in Chronic Inflammation and Autoimmunity}

\author{
Marina Babic ${ }^{1,2 *}$ and Chiara Romagnani ${ }^{1,2}$ \\ 1 Innate Immunity, German Rheumatism Research Center (DRFZ), Leibniz Association, Berlin, Germany, \\ ${ }^{2}$ Medical Department I, Charité - Universitätsmedizin Berlin, Berlin, Germany
}

Current medicine and medical science puts great effort into elucidating the basis of chronicity and finding appropriate treatments for inflammatory diseases; however, the mechanisms driving aberrant immune responses are mostly unknown and deserve further study. Of particular interest is the identification of checkpoints that regulate the function and differentiation of pro-inflammatory cells during pathogenesis, along with means of their modulation for therapeutic purposes. Natural killer group 2, member D (NKG2D) is a potent activator of the immune system, known as a sensor for "inducedself" ligands, i.e., cellular danger signals that, in the context of chronic inflammation and autoimmunity, can be presented by cells being exposed to an inflammatory cytokine milieu, endoplasmic reticulum stress, or cell death. Engagement by such ligands can be translated by NKG2D into activation or co-stimulation of NK cells and different subsets of $\mathrm{T}$ cells, respectively, thus contributing to the regulation of the inflammatory response. In this review, we discuss the current knowledge on the contribution of the NKG2D-NKG2DL signaling axis during intestinal inflammation, type 1 diabetes, multiple sclerosis, and rheumatoid arthritis, where the role of NKG2D has been associated either by aberrant expression of the receptor and its ligands and/or by functional data in corresponding mouse models.

Keywords: autoimmunity, natural killer group 2, member D, natural killer group 2, member D ligand, intestinal inflammation, rheumatoid arthritis, multiple sclerosis, type 1 diabetes

\section{INTRODUCTION}

Natural killer group 2, member D (NKG2D; encoded by the gene Klrk1) is a molecular sensor of stressed cells and a potent activator of the immune system, and is largely expressed by NK cells as well as $\mathrm{CD} 8^{+}$and $\gamma \delta^{+} \mathrm{T}$ cells (1). It binds to a variety of well-defined danger molecules, such as retinoic acid inducible early (RAE) $1 \alpha-\varepsilon, \mathrm{H} 60 \mathrm{a}-\mathrm{c}$ and murine UL-16-binding protein-like transcript (MULT)-1 in mice, or the MHC class-I-related chain (MIC)A/B and the UL-16 binding proteins (ULBP)1-6 in humans (2). The transcripts of NKG2D ligands are found in many tissues under healthy conditions but the cell surface expression of the corresponding proteins is kept under control by post-transcriptional regulation (3). Cellular stress, notably DNA damage, toll-like receptor signaling, and specific cytokine exposure can induce NKG2D ligand surface expression, as shown on tumor or virally infected cells (2). Ligand recognition by NKG2D can be integrated into a DNAX-activating protein (DAP)12- or DAP10-dependent signal, as in activated mouse NK cells, or into a DAP10-PI3K-mediated killing signal in human NK cells as well as a co-stimulation signal 
in human and mouse $\mathrm{CD} 8^{+} \mathrm{T}$ cells (4-6). Based on this, NKG2D plays an important role in immune surveillance by mediating direct recognition and clearance of infected and transformed cells expressing cognate ligands $(1,7,8)$. However, upregulation of NKG2D ligands has also been reported in tissue samples from patients with chronic inflammatory and autoimmune disorders as well as in in vivo experimental models thereof, and NKG2D ${ }^{+}$ cells have been implicated in their pathogenesis. Interestingly, in addition to $\mathrm{NK}, \mathrm{CD}^{+} \mathrm{T}$, and $\gamma \delta^{+} \mathrm{T}$ cells, increased frequency of rarely occurring $\mathrm{NKG}_{2} \mathrm{D}^{+} \mathrm{CD} 4^{+} \mathrm{T}$ cells has been observed in many different human pathologies (9-12) and in inflammatory models in mice $(13,14)$.

Here, we discuss the role of NKG2D-expressing cells as well as of NKG2D ligands during selected chronic inflammatory diseases, where the aberrant expression of the receptor and its ligands or data in corresponding mouse models implicate the role of NKG2D in the development of the respective disease.

\section{CELIAC AND INFLAMMATORY BOWEL DISEASES (IBDs)}

Celiac disease $(\mathrm{CeD})$ is a malabsorption syndrome that is elicited by gluten intolerance in individuals with genetic susceptibility. The pathology is manifested in massive cell death in the epithelial compartment which is infiltrated by autoreactive cytotoxic lymphocytes (CTL). The disruption in the homeostasis of intraepithelial lymphocytes (IEL) can additionally lead to the development of lymphoid malignancies, often associated with the refractory celiac sprue (RCS) (15), caused either by the clonal expansion of $\mathrm{T}$ cells or lately characterized $\mathrm{sCD}^{-} \mathrm{iCD}^{+}$innate IEL (16). Patients with active disease are characterized by high levels of IL-15 expressed by intestinal enterocytes and lamina propria (LP) mononuclear cells, which correlates with the degree of mucosal damage (17).

IL-15 seems to mediate priming of $\mathrm{CD}^{+} \mathrm{T}$ cells and turns them into potent cytolytic cells (18), which kill epithelial cells based on the recognition of stress signals (19). It became evident that IL-15 contributes to the cytotoxic potential of CTL by increasing the expression of NKG2D and its adaptor DAP10 in $\mathrm{CD}^{+} \mathrm{T}$ cells, and indeed, patients with active CeD display a 4to 20-fold higher expression of NKG2D on intraepithelial CTL, when compared with healthy individuals (18). Importantly, the expression of NKG2D ligands, namely, MICA, is upregulated in intestinal epithelial cells (IEC) as well as in mononuclear cells of patients. NKG2D blocking inhibited lysis of $\mathrm{MIC}^{+}$or $\mathrm{ULBP}^{+}$IEC lines (or of MICA-transfected tumor cell lines) by IL-15-primed human effector CTL, suggesting that upregulation of NKG2D on CTL converts them into potent killers (18). Conversely, the role of NKG2D expression by other $\mathrm{T}$ cell subsets or by innate lymphoid cells (ILC) during $\mathrm{CeD}$ has not been investigated so far.

The crucial role of gluten in the pathogenesis of $\mathrm{CeD}$ is also partially linked to the regulation of the NKG2D pathway. Interestingly, upon transition of patients to a gluten-free-diet (GFD), the levels of both NKG2D and MICA dropped, reaching levels observed in healthy controls, but remained high in
GFD-resistant RCS patients. Moreover, culturing intestinal samples with gliadin, resulted in the upregulation of MICA exclusively in patients on a GFD, but not in healthy controls. Upon testing of different gliadin-derived peptides, non-immunodominant p31-49 and immunodominant p57-89, it became clear that only p31 induced MICA expression (20). p31-49 induced IL-15 expression by LP dendritic cells and macrophages of $\mathrm{CeD}$ patients (21), and the p31-mediated upregulation of MICA could be blocked by $\alpha$-IL-15 neutralizing antibodies (20), suggesting that this might be a mechanism of how the sensing of gluten and IL-15 is integrated to result in the expression of NKG2D and MICA and contribute to CeD pathogenesis. Despite these interesting observations, data reporting on NKG2D or MIC polymorphisms in association with susceptibility to $\mathrm{CeD}$ are either absent or conflicting $(20,22,23)$ and the demonstration of a functional role of $\mathrm{NKG} 2 \mathrm{D}$ in an in vivo $\mathrm{CeD}$ experimental model is still missing to date.

Inflammatory bowel disease represents a group of intestinal disorders that cause prolonged inflammation of the digestive tract and is prominently represented by Crohn's disease (CD) and ulcerative colitis (UC). IBD is characterized by dysregulated gut microbiota, and an aberrant immune response, typically dominated by Th1 and Th17 cells during CD and Th2 cells during UC $(24,25)$. Association of the NKG2D-NKG2DL axis in the pathogenesis of IBD was implicated after the discovery of significantly upregulated MICA expression in IEC from CD and to a lesser extent from UC patients when compared with IEC from area-matched healthy controls (9). However, characterization of $\mathrm{CD}^{+} \mathrm{T}$ cells from the peripheral blood (PB) and LP of CD and UC patients or control individuals revealed an increase in the frequency of NKG2D ${ }^{+}$cells exclusively in $\mathrm{CD}$ patients. These cells displayed a Th1-like phenotype, reflected in perforin expression, secretion of IFN- $\gamma$ upon stimulation and cytotoxicity toward MICA-expressing targets (9). NKG2D ${ }^{+} \mathrm{CD} 4^{+} \mathrm{T}$ cells from LP of CD patients expressed IL-15R $\alpha$ and IL-15 provision increased NKG2D and DAP10 expression in $\mathrm{CD}^{+}{ }^{+} \mathrm{NKG}_{2} \mathrm{D}^{+}$clones, similarly as described for $\mathrm{CD}^{+} \mathrm{T}$ cells in $\mathrm{CeD}$. Whether IL-15 is the main and only factor driving NKG2D expression on $\mathrm{CD}^{+} \mathrm{T}$ cells remains to be determined. Following the discovery of Th17 cells and their role in mediation of intestinal inflammation, further profiling of NKG2D ${ }^{+} \mathrm{CD} 4^{+} \mathrm{T}$ cells from $\mathrm{CD}$ patients showed enrichment of IL-17-producing cells among NKG2D ${ }^{+} \mathrm{CD} 4^{+} \mathrm{T}$ cells when compared to the NKG2D ${ }^{-}$compartment. Co-stimulation of $\mathrm{CD}^{+}$ T cells via NKG2D resulted in expression of IL-17, IFN- $\gamma$, and TNF. IL-17A/IFN- $\gamma$ and IL-17A/IL-22 co-producers were specifically contained within $\mathrm{NKG}_{2} \mathrm{D}^{+} \mathrm{CD} 4^{+} \mathrm{T}$ cells $(26)$. T-cell receptor repertoire analysis showed that most $\mathrm{CD}^{+} \mathrm{T}$ cell oligoclonal expansions found in $\mathrm{PB}$ and small intestine $\mathrm{LP}$ of $\mathrm{CD}$ patients are contained within the $\mathrm{NKG}_{2} \mathrm{D}^{+}$subset (27). Interestingly, the expansions found in LP and $\mathrm{PB}$ were different, suggesting that the ones in the LP are a consequence of a local expansion. Two separate studies demonstrated accumulation of $\mathrm{NKG}_{2} \mathrm{D}^{+} \mathrm{CD} 4^{+}$ $\mathrm{T}$ cells in colon $\mathrm{LP}$ in a $\mathrm{CD}^{+}{ }^{+} \mathrm{T}$ cell transfer-induced colitis model and disease amelioration after treatment with blocking $\alpha$-NKG2D antibodies $(13,28)$.

Using a model of dextran sulfate sodium (DSS)-induced colitis, Qian and colleagues reported perturbation of numbers and 
frequency of $\mathrm{NKG}_{2} \mathrm{D}^{+} \mathrm{CD} 4^{+}$and $\mathrm{NKG}_{2} \mathrm{D}^{+} \mathrm{CD} 8^{+} \mathrm{T}$ cells in colon and spleen (29). Further dissection of splenic $\mathrm{NKG}_{2} \mathrm{D}^{+} \mathrm{CD} 4^{+}$ T cells according to NK1.1 expression revealed two major subsets, namely, TGF- $\beta^{+}$FasL $^{+}$T-bet ${ }^{+} \mathrm{NK} 1.1^{-}$cells and IFN- $\gamma^{+} \mathrm{IL}-17^{+} \mathrm{IL}-$ $21^{+}$granzymeB ${ }^{+}$perforin ${ }^{+}$T-bet ${ }^{-} \mathrm{ROR} \gamma \mathrm{t}^{+} \mathrm{NK} 1.1^{+}$cells. Transfer of $\mathrm{NK} 1.1^{-} \mathrm{NKG}_{2} \mathrm{D}^{+} \mathrm{CD} 4^{+} \mathrm{T}$ cells delayed the onset of DSS-induced colitis and the protective effect was dependent on TGF- $\beta$. Conversely, the transfer of $\mathrm{NK} 1.1^{+} \mathrm{NKG} 2 \mathrm{D}^{+} \mathrm{CD} 4^{+} \mathrm{T}$ cells exacerbated the colitis outcome.

An interesting study by Hosomi and colleagues demonstrated an important role of the NKG2D-NKG2DL interaction in recognition of endoplasmic reticulum stress by immune cells and how this is converted into intestinal inflammation (30). Mice with specific deletion of $X b p 1$, a crucial gene involved in unfolded protein response in IEC $\left(X b p 1^{\Delta \mathrm{IEC}}\right)$ showed increased expression of Ulbp1 (gene encoding MULT-1) in IEC, as well as spontaneous development of intestinal inflammation. This process seems to be mediated by direct binding of the transcription factor, named CCAAT-enhancer-binding protein homologous protein (CHOP), to the promotor region of Ulbp1 in IEC. Spontaneous enteritis was ameliorated by treatment with an $\alpha$-NKG2Dblocking antibody as well as by depletion of NK1.1+ cells that include cytolytic NKG2D-expressing group 1 ILC. Despite increased frequency of intraepithelial NKG2D $\mathrm{D}^{+} \gamma \delta^{+} \mathrm{T}$ cells observed in $X b p 1^{\Delta \mathrm{IEC}}$ mice, $\gamma \delta^{+}$or $\alpha \beta^{+} \mathrm{T}$ cells play a redundant role in causing spontaneous intestinal inflammation in this model (30). Altogether, these reports show that upregulation of NKG2D ligands might represent a common response to intestinal epithelium stress, rendering IEC susceptible to NKG2D-mediated immune surveillance and regulation.

\section{TYPE 1 DIABETES (T1D)}

During T1D, the body's own immune system attacks the $\beta$-cells in the pancreatic islets resulting in damage, reduced and subsequently abrogated insulin production (31). Genetically susceptible individuals carry the high-risk HLA DR4-DQ8 and DR3-DQ2 haplotype in more than $90 \%$ of cases. Although it is generally believed that the disease is mediated by self-reactive $\mathrm{CD}^{+}$and $\mathrm{CD}^{+} \mathrm{T}$ cells and macrophages, a role for regulatory $\mathrm{T}$ cells in the regulation of diabetogenic IFN- $\gamma$-producing NK cells in the pancreatic islets has been described $(32,33)$. In humans, genetic linkage studies showed positive association of the MICA allele 5 with T1D (34). The role of NKG2D in T1D pathogenesis has been assessed mainly using the non-obese diabetic (NOD) mice, with conflicting conclusions (35-37). An initial study reported Raet1 transcripts (encoding for RAE1) in the $\beta$-cells of the pancreas of 4- to 6-week-old NOD mice and linked an increase in Raet1 expression with age (36). Following studies could not confirm the expression of Raet 1 in pancreatic $\beta$-cells of NOD mice (37-39), while Trembath et al. rather observed expression of $\mathrm{H} 60 \mathrm{a}$ in pancreas-infiltrating T cells (37). A pathogenic role for NKG2D was reported by Ogasawara et al. (36), who demonstrated that antibody-mediated blocking of NKG2D signaling led to reduced infiltration of autoreactive $\mathrm{CD}^{+} \mathrm{T}$ cells into the pancreas of 16-week-old NOD mice and decreased diabetes incidence. Along this line, by using the C57BL/6J mice with transgenic expression of RAE1 1 in islet $\beta$-cells of the pancreas (Rae1-Tg mice), it was shown that CTL were recruited to the pancreas of Rae1-Tg mice in an antigen-independent but NKG2D-dependent manner (40). Although transgenic expression of RAE1 led to spontaneous insulitis in old Rae1-Tg mice, no diabetes development could be observed in this model. Disease amelioration by antibodymediated blocking of NKG2D signaling in NOD mice, as initially reported by the Lanier group (36), could not be reproduced in the report by Guerra et al. (35). In addition, crossing of NKG2Ddeficient mice to the NOD background $\left(\mathrm{NOD} \times \mathrm{Klrk1}^{--}\right.$) did not result in any disease amelioration (35), questioning the role of NKG2D in this disease model.

One potential explanation of such discrepancies can be related to microflora differences, which appear to impact T1D incidence in NOD mice $(41,42)$. Interestingly, Trembath and colleagues reported that $K l r k 1^{-1-}$ NOD mice have lower diabetes incidence when compared with littermate NOD mice housed in specific pathogen-free conditions; however, this effect was lost and even reversed upon treatment of NOD and $K l r k 1^{-1-}$ NOD littermate mice with broad-spectrum antibiotics (37). Supporting this hypothesis, it was shown that treatment of C57BL/6N mice with vancomycin can reduce the expression of Raet 1 in small intestine epithelium, and this effect was correlated with the presence of $A$. muciniphila in the vancomycin-treated mice (43).

In light of these data, the role of NKG2D in T1D autoimmunity should be reconsidered by taking into account the differences in colonizing microbiota. In addition, the contribution of other NKG2D-expressing cell types to the regulation of T1D needs further evaluation.

\section{MULTIPLE SCLEROSIS (MS) AND EXPERIMENTAL AUTOIMMUNE ENCEPHALOMYELITIS (EAE)}

Multiple sclerosis, an inflammatory disease of the central nervous system (CNS), is characterized by the loss of oligodendrocytes, followed by a reduction in myelin production. While $\mathrm{CD}^{+}$ $\mathrm{T}$ cells predominate in acute lesions of MS patients and are better studied in the EAE, a mouse model of MS (44), CD8 ${ }^{+} \mathrm{T}$ cells seem to play an important role in tissue damage and are observed more frequently in the chronic lesions of MS patients $(45,46)$. Patients display elevated levels of soluble MICB but not MICA in the sera (47) and the $\mathrm{MICB}^{\star} 004$ allele was associated with higher MS susceptibility (48), suggesting a role for NKG2D signaling in the development of MS. Similar to other inflammatory diseases, IL-15 was elevated in the serum of MS patients and could be expressed ex vivo in astrocytes and infiltrating macrophages from MS lesions (49). Astrocyte-derived IL-15 reinforced the cytotoxic program in $\mathrm{CD}^{+}$and $\mathrm{CD}^{+} \mathrm{T}$ cells, with increased expression of NKG2D, perforin, and granzyme $(49,50)$. MICA/B ligand engagement on human oligodendrocytes could induce their killing in vitro by IL- 2 activated NK cells, $\gamma \delta^{+} \mathrm{T}$ cells, or polyclonal $\mathrm{CD}^{+} \mathrm{T}$ cells in an NKG2D-dependent fashion (50).

Multiple sclerosis patients are characterized by an enrichment in $\mathrm{NKG}_{2} \mathrm{D}^{+} \mathrm{CD}^{+}$but not $\mathrm{CD} 8^{+} \mathrm{T}$ cells in cerebrospinal fluid and in inflammatory lesions (51), as compared to $\mathrm{PB}$ and to healthy 
donors, which might be a result of a local expansion mediated by an inflamed milieu or an increased migratory capacity (49). In the same study, by using the EAE model, the authors could show that treatment of mice with a blocking $\alpha-\mathrm{NKG} 2 \mathrm{D}$ antibody after immunization, but before disease onset, resulted in a reduced disease score (51), which could partially be reproduced by using $K l r k 1^{-1-}$ mice (35). The treatment did not seem to affect peripheral cell activation, but rather the infiltration of $\mathrm{NKG}_{2} \mathrm{D}^{+} \mathrm{CD} 4^{+}$ and $\mathrm{NKG}_{2} \mathrm{D}^{+} \mathrm{CD} 8^{+} \mathrm{T}$ cells into CNS at the peak of the disease. Moreover, Raet 1 transcripts were detected in myeloid cells in the spinal cord of the EAE mice, with expression levels correlating with the disease score (52). It was suggested that $\mathrm{NKG}_{2} \mathrm{D}^{+} \mathrm{CD} 4^{+}$ T cells might contribute to killing of oligodendrocytes. Similar to human, in vitro cultured and cytokine activated mouse oligodendrocytes expressing MULT-1 and RAE1 were susceptible to killing by $\alpha$-CD3/ $\alpha$-CD2 8 activated $C D 4^{+} \mathrm{T}$ cells enriched for the expression of NKG2D to $8-12 \%$ (51). Although the killing mechanism remains unclear, it seems to be partially reduced by blocking of NKG2D, and independent of MHC class I or II peptide presentation.

While accumulation of $\mathrm{NKG}_{2} \mathrm{D}^{+} \mathrm{CD} 4^{+} \mathrm{T}$ cells into $\mathrm{CNS}$ of EAE and MS remains an interesting finding, the contribution of NKG2D on various cell types in mediating cell priming in the periphery, migration into the tissue and reactivation in situ needs to be further explored.

\section{RHEUMATOID ARTHRITIS (RA) AND MODELS OF JOINT INFLAMMATION}

Rheumatoid arthritis is a chronic inflammatory disease that causes inflammation and destruction of the joints. The disease is characterized by high levels of TNF and IL-15 which are found in patient sera (10) and prominently mediated by joint-infiltrating autoreactive $\mathrm{CD} 4^{+} \mathrm{T}$ cells that promote autoantibody production by plasma cells, along with macrophage and endothelial activation (53). It was shown that TNF and IL-15 could upregulate NKG2D in vitro on $\mathrm{PB} \mathrm{CD} 4{ }^{+} \mathrm{T}$ cells or on $\mathrm{NKG}_{2} \mathrm{D}^{-} \mathrm{CD} 4^{+} \mathrm{T}$ cells from the inflamed synovia of RA patients. Indeed, around $18 \%$ of potentially autoreactive $\mathrm{CD} 28^{-} \mathrm{CD} 4^{+} \mathrm{T}$ cells from the $\mathrm{PB}$ and synovial tissue of RA patients expressed NKG2D. Membrane bound MICA and MICB were abundantly expressed in the synoviocytes of RA patients and could trigger autologous autoreactive T cells in an NKG2D-dependent manner (54). Crosslinking of NKG2D on $\mathrm{CD}^{+}{ }^{+} \mathrm{CD} 28^{-} \mathrm{T}$ cells seemed to co-stimulate TCR-mediated secretion of IFN- $\gamma$ and TNF as well as proliferation (10).

Single-nucleotide polymorphisms in both MICA and NKG2D have been associated with RA, suggesting MICA and NKG2D as RA susceptibility genes $(55,56)$. Moreover, a recent study evaluated the role of polymorphisms in KLRK1 gene with efficacy of $\alpha$-TNF therapy in RA patients (57), identifying two polymorphisms associated with better response and two polymorphisms associated with inefficient response to therapy. More functional studies that would dissect the direct effect of the polymorphisms to the TNF production and resistance to $\alpha$-TNF therapy would be beneficial to understand the impact of this association.

Using a collagen-induced arthritis (CIA) model, Andersson and colleagues could demonstrate that the treatment of mice with a blocking $\alpha$-NKG2D antibody reduced the clinical score, even when applied after the disease onset (14). Along this line, NKG2D-blocking preserved joint architecture and reduced infiltration of $\gamma \delta^{+}$and $\mathrm{CD}^{+} \mathrm{T}$ cells in mouse paws, while it did not affect $\mathrm{CD}^{+} \mathrm{T}$ and NK cells. This study also reported that treatment with an $\alpha-\mathrm{NKG} 2 \mathrm{D}$-blocking antibody reduced infiltration of $\mathrm{IL}-17^{+} \mathrm{CD} 4^{+}$but not of $\mathrm{IL}-17^{+} \gamma \delta^{+} \mathrm{T}$ cells in the paws. Interestingly, the per-cell expression of NKG2D on NK cells was slightly reduced during late CIA, possibly related to chronic exposure of these cells to the ligands. Similar to what was observed in human RA samples, NKG2D ligand expression did not affect the expression of NKG2D on $\gamma \delta^{+}$and CD $4^{+} \mathrm{T}$ cells, suggesting different regulation of NKG2D expression on innate and adaptive cells.

\section{CONCLUDING REMARKS}

Current data support the role of inflammatory cytokine- and endoplasmic reticulum stress-induced expression of NKG2D ligands in several immune-mediated diseases, suggesting that the NKG2D-NKG2DL axis can represent an interesting target for the modulation of selective inflammatory disorders. Recently, the efficacy of a blocking $\alpha$-NKG2D antibody was tested within phase I/II clinical trial that included 78 patients diagnosed with $\mathrm{CD}$. No difference between the single dose treated and placebo receiving cohort was observed at week 4 , but effects became visible at week 12 as manifested in a significant clinical response in patients responding to biological therapy or those with untreated disease (58). A phase I/II study with a blocking $\alpha-\mathrm{NKG} 2 \mathrm{D}$ antibody was also performed in a cohort of patients diagnosed with RA, however, with no published results to date. The field would benefit from functional studies performed in vivo, which would allow comparisons between complete NKG2D-deficient mice to mice with cell-specific NKG2D-deficiency (59), as well as from studies in mice with conditional deficiency of NKG2D ligands (60). Given the complexity of the regulation of NKG2D ligand expression and the possibly multifaceted role of microbiota, understanding the specific role of each $\mathrm{NKG}_{2} \mathrm{D}^{+}$population in the pathogenesis of the particular disease would enable better design of future therapeutic approaches.

\section{AUTHOR CONTRIBUTIONS}

$\mathrm{MB}$ searched the literature and wrote the majority of the manuscript. CR contributed to writing and editing of the manuscript.

\section{ACKNOWLEDGMENTS}

We thank Daniela Hernández-Torres for reading the manuscript. We apologize to our colleagues whose work is not cited due to space restrictions. This work was supported by the Leibniz ScienceCampus Chronic Inflammation (www.chronischeentzuendung.org) and by the German Research Foundation (DFG) grants RO3565/2-1 and RO3565/4-1 to CR and European Union Framework Program 7, Marie Curie Intraeuropean Fellowship 327643 to MB. CR is supported by the DFG Heisenberg Program (RO3565/1-1). 


\section{REFERENCES}

1. Lanier LL. NKG2D receptor and its ligands in host defense. Cancer Immunol Res (2015) 3(6):575-82. doi:10.1158/2326-6066.CIR-15-0098

2. Raulet DH, Gasser S, Gowen BG, Deng W, Jung H. Regulation of ligands for the NKG2D activating receptor. Annu Rev Immunol (2013) 31:413-41. doi:10.1146/annurev-immunol-032712-095951

3. Nice TJ, Coscoy L, Raulet DH. Posttranslational regulation of the NKG2D ligand Mult1 in response to cell stress. JExp Med (2009) 206(2):287-98. doi:10.1084/jem.20081335

4. Diefenbach A, Tomasello E, Lucas M, Jamieson AM, Hsia JK, Vivier E, et al. Selective associations with signaling proteins determine stimulatory versus costimulatory activity of NKG2D. Nat Immunol (2002) 3(12):1142-9. doi: $10.1038 /$ ni858

5. Gilfillan S, Ho EL, Cella M, Yokoyama WM, Colonna M. NKG2D recruits two distinct adapters to trigger NK cell activation and costimulation. Nat Immunol (2002) 3(12):1150-5. doi:10.1038/ni857

6. Billadeau DD, Upshaw JL, Schoon RA, Dick CJ, Leibson PJ. NKG2DDAP10 triggers human NK cell-mediated killing via a Syk-independent regulatory pathway. Nat Immunol (2003) 4(6):557-64. doi:10.1038/ni929

7. Strid J, Sobolev O, Zafirova B, Polic B, Hayday A. The intraepithelial T cell response to NKG2D-ligands links lymphoid stress surveillance to atopy. Science (2011) 334(6060):1293-7. doi:10.1126/science.1211250

8. Jonjic S, Babic M, Polic B, Krmpotic A. Immune evasion of natural killer cells by viruses. Curr Opin Immunol (2008) 20(1):30-8. doi:10.1016/j.coi.2007.11.002

9. Allez M, Tieng V, Nakazawa A, Treton X, Pacault V, Dulphy N, et al. CD4+NKG2D+ T cells in Crohn's disease mediate inflammatory and cytotoxic responses through MICA interactions. Gastroenterology (2007) 132(7):2346-58. doi:10.1053/j.gastro.2007.03.025

10. Groh V, Bruhl A, El-Gabalawy H, Nelson JL, Spies T. Stimulation of T cell autoreactivity by anomalous expression of NKG2D and its MIC ligands in rheumatoid arthritis. Proc Natl Acad Sci U S A (2003) 100(16):9452-7. doi:10.1073/pnas.1632807100

11. Dai Z, Turtle CJ, Booth GC, Riddell SR, Gooley TA, Stevens AM, et al. Normally occurring NKG2D+CD4+ T cells are immunosuppressive and inversely correlated with disease activity in juvenile-onset lupus. J Exp Med (2009) 206(4): 793-805. doi:10.1084/jem.20081648

12. Saez-Borderias A, Guma M, Angulo A, Bellosillo B, Pende D, Lopez-Botet M. Expression and function of NKG2D in CD4+ T cells specific for human cytomegalovirus. Eur J Immunol (2006) 36(12):3198-206. doi:10.1002/eji. 200636682

13. Ito $\mathrm{Y}$, Kanai T, Totsuka T, Okamoto R, Tsuchiya $\mathrm{K}$, Nemoto $\mathrm{Y}$, et al. Blockade of NKG2D signaling prevents the development of murine CD4+ T cell-mediated colitis. Am J Physiol Gastrointest Liver Physiol (2008) 294(1): G199-207. doi:10.1152/ajpgi.00286.2007

14. Andersson AK, Sumariwalla PF, McCann FE, Amjadi P, Chang C, McNamee K, et al. Blockade of NKG2D ameliorates disease in mice with collagen-induced arthritis: a potential pathogenic role in chronic inflammatory arthritis. Arthritis Rheum (2011) 63(9):2617-29. doi:10.1002/art.30460

15. Mention JJ, Ben Ahmed M, Begue B, Barbe U, Verkarre V, Asnafi V, et al. Interleukin 15: a key to disrupted intraepithelial lymphocyte homeostasis and lymphomagenesis in celiac disease. Gastroenterology (2003) 125(3):730-45. doi:10.1016/S0016-5085(03)01047-3

16. Ettersperger J, Montcuquet N, Malamut G, Guegan N, Lopez-Lastra S, Gayraud S, et al. Interleukin-15-dependent T-cell-like innate intraepithelial lymphocytes develop in the intestine and transform into lymphomas in celiac disease. Immunity (2016) 45(3):610-25. doi:10.1016/j.immuni.2016.07.018

17. Di Sabatino A, Ciccocioppo R, Cupelli F, Cinque B, Millimaggi D, Clarkson MM, et al. Epithelium derived interleukin 15 regulates intraepithelial lymphocyte Th1 cytokine production, cytotoxicity, and survival in coeliac disease. Gut (2006) 55(4):469-77. doi:10.1136/gut.2005.068684

18. Meresse B, Chen Z, Ciszewski C, Tretiakova M, Bhagat G, Krausz TN, et al. Coordinated induction by IL15 of a TCR-independent NKG2D signaling pathway converts CTL into lymphokine-activated killer cells in celiac disease. Immunity (2004) 21(3):357-66. doi:10.1016/j.immuni.2004.06.020

19. Roberts AI, Lee L, Schwarz E, Groh V, Spies T, Ebert EC, et al. NKG2D receptors induced by IL-15 costimulate CD28-negative effector CTL in the tissue microenvironment. J Immunol (2001) 167(10):5527-30. doi:10.4049/ jimmunol.167.10.5527
20. Hue S, Mention JJ, Monteiro RC, Zhang S, Cellier C, Schmitz J, et al. A direct role for NKG2D/MICA interaction in villous atrophy during celiac disease. Immunity (2004) 21(3):367-77. doi:10.1016/j.immuni.2004.06.018

21. Maiuri L, Ciacci C, Ricciardelli I, Vacca L, Raia V, Auricchio S, et al. Association between innate response to gliadin and activation of pathogenic $\mathrm{T}$ cells in coeliac disease. Lancet (2003) 362(9377):30-7. doi:10.1016/S01406736(03)13803-2

22. Tinto N, Ciacci C, Calcagno G, Gennarelli D, Spampanato A, Farinaro E, et al. Increased prevalence of celiac disease without gastrointestinal symptoms in adults MICA 5.1 homozygous subjects from the Campania area. Dig Liver Dis (2008) 40(4):248-52. doi:10.1016/j.dld.2007.11.028

23. Bilbao JR, Martin-Pagola A, Vitoria JC, Zubillaga P, Ortiz L, Castano L. HLA-DRB1 and MHC class 1 chain-related A haplotypes in Basque families with celiac disease. Tissue Antigens (2002) 60(1):71-6. doi:10.1034/j.1399-0039. 2002.600109.x

24. Baumgart DC, Sandborn WJ. Crohn's disease. Lancet (2012) 380(9853): 1590-605. doi:10.1016/S0140-6736(12)60026-9

25. Brand S. Crohn's disease: Th1, Th17 or both? The change of a paradigm: new immunological and genetic insights implicate Th17 cells in the pathogenesis of Crohn's disease. Gut (2009) 58(8):1152-67. doi:10.1136/gut.2008.163667

26. Pariente B, Mocan I, Camus M, Dutertre CA, Ettersperger J, Cattan P, et al. Activation of the receptor NKG2D leads to production of Th17 cytokines in CD4+ T cells of patients with Crohn's disease. Gastroenterology (2011) 141(1):217-26, 226.e1-2. doi:10.1053/j.gastro.2011.03.061

27. Camus M, Esses S, Pariente B, Le Bourhis L, Douay C, Chardiny V, et al. Oligoclonal expansions of mucosal T cells in Crohn's disease predominate in NKG2D-expressing CD4 T cells. Mucosal Immunol (2014) 7(2):325-34. doi:10.1038/mi.2013.51

28. Kjellev S, Haase C, Lundsgaard D, Urso B, Tornehave D, Markholst H. Inhibition of NKG2D receptor function by antibody therapy attenuates transfer-induced colitis in SCID mice. Eur J Immunol (2007) 37(5):1397-406 doi:10.1002/eji.200636473

29. Qian X, Hu C, Han S, Lin Z, Xiao W, Ding Y, et al. NK1.1(-) CD4(+) $\mathrm{NKG} 2 \mathrm{D}(+) \mathrm{T}$ cells suppress DSS-induced colitis in mice through production of TGF-beta. J Cell Mol Med (2017) 21(7):1431-44. doi:10.1111/ jcmm.13072

30. Hosomi S, Grootjans J, Tschurtschenthaler M, Krupka N, Matute JD, Flak MB, et al. Intestinal epithelial cell endoplasmic reticulum stress promotes MULT1 up-regulation and NKG2D-mediated inflammation. J Exp Med (2017) 214(10):2985-97. doi:10.1084/jem.20162041

31. Atkinson MA, Eisenbarth GS. Type 1 diabetes: new perspectives on disease pathogenesis and treatment. Lancet (2001) 358(9277):221-9. doi:10.1016/ S0140-6736(01)05415-0

32. Feuerer M, Shen Y, Littman DR, Benoist C, Mathis D. How punctual ablation of regulatory $\mathrm{T}$ cells unleashes an autoimmune lesion within the pancreatic islets. Immunity (2009) 31(4):654-64. doi:10.1016/j.immuni.2009.08.023

33. Sitrin J, Ring A, Garcia KC, Benoist C, Mathis D. Regulatory T cells control NK cells in an insulitic lesion by depriving them of IL-2. J Exp Med (2013) 210(6):1153-65. doi:10.1084/jem.20122248

34. Nikitina-Zake L, Rajalingham R, Rumba I, Sanjeevi CB. Killer cell immunoglobulin-like receptor genes in Latvian patients with type 1 diabetes mellitus and healthy controls. Ann N Y Acad Sci (2004) 1037:161-9. doi:10.1196/annals. 1337.027

35. Guerra N, Pestal K, Juarez T, Beck J, Tkach K, Wang L, et al. A selective role of NKG2D in inflammatory and autoimmune diseases. Clin Immunol (2013) 149(3):432-9. doi:10.1016/j.clim.2013.09.003

36. Ogasawara K, Hamerman JA, Ehrlich LR, Bour-Jordan H, Santamaria P, Bluestone JA, et al. NKG2D blockade prevents autoimmune diabetes in NOD mice. Immunity (2004) 20(6):757-67. doi:10.1016/j.immuni.2004.05.008

37. Trembath AP, Sharma N, Raju S, Polic B, Markiewicz MA. A protective role for NKG2D-H60a interaction via homotypic T cell contact in nonobese diabetic autoimmune diabetes pathogenesis. Immunohorizons (2017) 1(9):198-212. doi:10.4049/immunohorizons.1700011

38. Angstetra E, Graham KL, Zhao Y, Irvin AE, Elkerbout L, Santamaria P, et al An indirect role for NK cells in a CD4(+) T-cell-dependent mouse model of type I diabetes. Immunol Cell Biol (2012) 90(2):243-7. doi:10.1038/icb.2011.16

39. Carrero JA, Calderon B, Towfic F, Artyomov MN, Unanue ER. Defining the transcriptional and cellular landscape of type 1 diabetes in the NOD mouse. PLoS One (2013) 8(3):e59701. doi:10.1371/journal.pone.0059701 
40. Markiewicz MA, Wise EL, Buchwald ZS, Pinto AK, Zafirova B, Polic B, et al. RAElepsilon ligand expressed on pancreatic islets recruits NKG2D receptor-expressing cytotoxic $\mathrm{T}$ cells independent of $\mathrm{T}$ cell receptor recognition. Immunity (2012) 36(1):132-41. doi:10.1016/j.immuni.2011.11.014

41. King C, Sarvetnick N. The incidence of type-1 diabetes in NOD mice is modulated by restricted flora not germ-free conditions. PLoS One (2011) 6(2):e17049. doi:10.1371/journal.pone.0017049

42. Kriegel MA, Sefik E, Hill JA, Wu HJ, Benoist C, Mathis D. Naturally transmitted segmented filamentous bacteria segregate with diabetes protection in nonobese diabetic mice. Proc Natl Acad Sci U S A (2011) 108(28):11548-53. doi:10.1073/pnas.1108924108

43. Hansen CH, Holm TL, Krych L, Andresen L, Nielsen DS, Rune I, et al. Gut microbiota regulates NKG2D ligand expression on intestinal epithelial cells. Eur J Immunol (2013) 43(2):447-57. doi:10.1002/eji.201242462

44. Petermann F, Korn T. Cytokines and effector T cell subsets causing autoimmune CNS disease. FEBS Lett (2011) 585(23):3747-57. doi:10.1016/j.febslet. 2011.03.064

45. Sospedra M, Martin R. Immunology of multiple sclerosis. Annu Rev Immunol (2005) 23:683-747. doi:10.1146/annurev.immunol.23.021704.115707

46. Chitnis T. The role of CD4 T cells in the pathogenesis of multiple sclerosis. Int Rev Neurobiol (2007) 79:43-72. doi:10.1016/S0074-7742(07)79003-7

47. Fernandez-Morera JL, Rodriguez-Rodero S, Lahoz C, Tunon A, Astudillo A, Garcia-Suarez O, et al. Soluble MHC class I chain-related protein B serum levels correlate with disease activity in relapsing-remitting multiple sclerosis. Hum Immunol (2008) 69(4-5):235-40. doi:10.1016/j.humimm.2008.01.021

48. Fernandez-Morera JL, Rodriguez-Rodero S, Tunon A, Martinez-Borra J, Vidal-Castineira JR, Lopez-Vazquez A, et al. Genetic influence of the nonclassical major histocompatibility complex class I molecule MICB in multiple sclerosis susceptibility. Tissue Antigens (2008) 72(1):54-9. doi:10.1111/j.13990039.2008.01066.x

49. Broux B, Mizee MR, Vanheusden M, van der Pol S, van Horssen J, Van Wijmeersch B, et al. IL-15 amplifies the pathogenic properties of CD4+CD28T cells in multiple sclerosis. J Immunol (2015) 194(5):2099-109. doi:10.4049/ jimmunol.1401547

50. Saikali P, Antel JP, Pittet CL, Newcombe J, Arbour N. Contribution of astrocyte-derived IL-15 to CD8 T cell effector functions in multiple sclerosis. J Immunol (2010) 185(10):5693-703. doi:10.4049/jimmunol.1002188

51. Ruck T, Bittner S, Gross CC, Breuer J, Albrecht S, Korr S, et al. CD4+NKG2D+ $\mathrm{T}$ cells exhibit enhanced migratory and encephalitogenic properties in neuroinflammation. PLoS One (2013) 8(11):e81455. doi:10.1371/journal.pone. 0081455

52. Djelloul M, Popa N, Pelletier F, Raguenez G, Boucraut J. RAE-1 expression is induced during experimental autoimmune encephalomyelitis and is correlated with microglia cell proliferation. Brain Behav Immun (2016) 58:209-17. doi:10.1016/j.bbi.2016.07.147

53. Firestein GS, McInnes IB. Immunopathogenesis of rheumatoid arthritis. Immunity (2017) 46(2):183-96. doi:10.1016/j.immuni.2017.02.006

54. Groh V, Smythe K, Dai Z, Spies T. Fas-ligand-mediated paracrine T cell regulation by the receptor NKG2D in tumor immunity. Nat Immunol (2006) 7(7):755-62. doi:10.1038/ni1350

55. Kirsten H, Petit-Teixeira E, Scholz M, Hasenclever D, Hantmann H, Heider D, et al. Association of MICA with rheumatoid arthritis independent of known HLA-DRB1 risk alleles in a family-based and a case control study. Arthritis Res Ther (2009) 11(3):R60. doi:10.1186/ar2683

56. Mariaselvam CM, Tamouza R, Krishnamoorthy R, Charron D, Misra DP, Jain VK, et al. Association of NKG2D gene variants with susceptibility and severity of rheumatoid arthritis. Clin Exp Immunol (2017) 187(3):369-75. doi:10.1111/cei.12891

57. Iwaszko M, Swierkot J, Kolossa K, Jeka S, Wiland P, Bogunia-Kubik K. Influence of NKG2D genetic variants on response to anti-TNF agents in patients with rheumatoid arthritis. Genes (Basel) (2018) 9(2): 64. doi:10.3390/ genes 9020064

58. Allez M, Skolnick BE, Wisniewska-Jarosinska M, Petryka R, Overgaard RV. Anti-NKG2D monoclonal antibody (NNC0142-0002) in active Crohn's disease: a randomised controlled trial. Gut (2017) 66(11):1918-25. doi:10.1136/ gutjnl-2016-311824

59. Zafirova B, Wensveen FM, Gulin M, Polic B. Regulation of immune cell function and differentiation by the NKG2D receptor. Cell Mol Life Sci (2011) 68(21):3519-29. doi:10.1007/s00018-011-0797-0

60. Deng W, Gowen BG, Zhang L, Wang L, Lau S, Iannello A, et al. Antitumor immunity. A shed NKG2D ligand that promotes natural killer cell activation and tumor rejection. Science (2015) 348(6230):136-9. doi:10.1126/science. 1258867

Conflict of Interest Statement: The authors declare that the research was conducted in the absence of any commercial or financial relationships that could be construed as a potential conflict of interest.

The reviewer DA and handling Editor declared their shared affiliation.

Copyright (C) 2018 Babic and Romagnani. This is an open-access article distributed under the terms of the Creative Commons Attribution License (CC BY). The use, distribution or reproduction in other forums is permitted, provided the original author(s) and the copyright owner are credited and that the original publication in this journal is cited, in accordance with accepted academic practice. No use, distribution or reproduction is permitted which does not comply with these terms. 